DOI: 10.46340/eujem.2020.6.4.13

Olha Vovk, PhD in Economics

ORCID ID: 0000-0002-1680-1959

National Aviation University, Ukraine

\title{
METHODOLOGICAL BASES OF FORMATION OF THE MECHANISM THAT IMPLEMENTS MODERNIZATION POTENTIAL OF THE INFRASTRUCTURE ENTERPRISES
}

Ольга Вовк, к. е. н. Національний авіаційний університет, Україна

\section{МЕТОДОЛОГІЧНІ ЗАСАДИ ФОРМУВАННЯ МЕХАНІЗМУ РЕАЛІЗАЦІЇ МОДЕРНІЗАЦІЙНОГО ПОТЕНЦАЛУ ПІДПРИЕМСТВ ІНФРАСТРУКТУРНОЇ СФЕРИ}

The purpose of the study is to substantiate the methodological foundations of the modernization of infrastructure enterprises. The article considers the concept of modernization, its features, and purposefulness at the infrastructure enterprises. The author reveals modern patterns and requests for the modernization of enterprises. Thus, the implementation of international law and institutional incentives determine the directions of modernization; formation of multimodal transport and logistics complexes, innovation clusters and hubs; the emergence of services that become new sources of income and funding for innovative development.

The development of the organizational and economic mechanism is a tool for formalizing the sequence and system of targeted influences on the process of modernization of infrastructure enterprises. The author proposes axiological, theoretical, and practical bases of modernization management on the basis of modern theories of technological ways, neo-industrialism, and innovation. The proposed scheme of organizational and economic mechanisms for the implementation of the modernization potential of infrastructure enterprises includes the target, management, methodological and resulting subsystems.

Keywords: modernization potential, implementation mechanism, infrastructure enterprises, innovation paradigm, neo-industrialism, methodological support.

Постановка проблеми. Структурні диспропорції на підприємствах інфраструктурної сфери виникають як в результаті історичної економічної еволюції та відповідного старіння активів й технологій, так і внаслідок запитів щодо нарощування конкурентоспроможності, ефективності, що забезпечується впровадженням інноваційних технологій. Узгодження цілей розвитку підприємства та зазначених диспропорцій вирішується шляхом запровадження методологічних засад стратегічного управління інноваційним процесам - модернізацією. Формування теоретичного та практичного базису реалізації методичних положень модернізації стає ключовим завданням для активізації акумульованого потенціалу підприємства.

Аналіз основних досліджень і публікацій. Прикладні та методологічні площини управління модернізацією останніми роками досить грунтовно досліджувались на національному та регіональному рівнях управління економічними системами. Такі науковці як Касіч О.А. ${ }^{1}$, Балджи М.Д. ${ }^{2}$ та Рера T. ${ }^{3}$ розкрили економічну сутність, класифікацію, принципи та закономірності

\footnotetext{
${ }^{1}$ Касіч, А. О. (2017). Модернізаційні процеси в Україні в контексті світового досвіду. Економіка Украӥни, 9 (670), 38-58.

${ }^{2}$ Балджи, М. Д. (2015). Сутність модернізації в контексті сучасної економічної категорії. Науковий вісник Херсонського державного університету, 11, 64-67.

${ }^{3}$ Рера, Т., Чернюк, Л. (2017). Потенціал модернізації як базис ефективного соціально-економічного розвитку країни в контурі відтворювальних процесів. Збірник наукових працьь ЧДТУ, 44, 42-49.
} 
модернізації економічних систем. В контексті розробки методичних засад модернізації окремих промислових галузей заслуговують на увагу публікації Петровича Й.M. ${ }^{1}$, Федулововї Л.І. ${ }^{2}$. Дослідженням ресурсного, інвестиційного та організаційного забезпечення формуванню і реалізації потенціалу підприємств присвячено дослідження в наукових школах Ареф'євої О.В. ${ }^{3}$, Кучерук Г.Ю. ${ }^{4}$ та Тульчинської С.О. ${ }^{5}$. розглянутий теоретичний базис розкриває передумови та перспективи формування методичних положень організаційно-економічного механізму реалізації модернізаційного потенціалу підприємств.

Формулювання цілей статті. Сучасні наукові досягнення в теорії управління модернізаційним потенціалом потребую актуалізації для застосування на підприємствах інфраструктурної сфери. Метою дослідження $\epsilon$ обгрунтування організаційно-економічного механізму реалізації модернізаційного потенціалу інфраструктурних підприємств.

Опис основного матеріалу дослідження. Модернізація підприємства - це процес технікотехнологічного та управлінського оновлення, що орієнтовано на реалізацію стратегічних завдань інноваційного розвитку, нарощування якості продукції та конкурентоспроможності. Системність і послідовність модернізаційних змін мають відповідати цілям неотехнологічного прогресу в суспільноекономічних системах, інституційним реформам на мезо- та макрорівнях зовнішнього середовища, а також темпам інтелектуалізації й інноваційності в інтегрованому міжнародному просторі.

Основними цілями реалізації механізму модернізації підприємств інфраструктурної сфери є:

- інноваційне оновлення техніки, технологій та систем управління на засадах постіндустріалізму;

- розвиток професійних компетенцій та вмотивованості людини, як рушійного засобу нарощування ефективності,

- нарощування інтелектуального капіталу та інноваційного потенціалу для забезпечення можливостей інноваційного розвитку,

- пошук та активізація інвестиційних джерел фінансування інновацій,

- актуалізація пріоритетних об'єктів інвестування та інноваційного оновлення,

- розробка й застосування специфічних підходів до реалізації механізму модернізації, контроль за вартістю, часовими і просторовими ресурсами, досягненням поставлених завдань,

- відповідність міжнародним стандартам, сертифікація, дотримання міжнародних норм безпеки і якості послуг інфраструктурної сфери в процесах інноваційного оновлення,

- запровадження принципів постійних техніко-інноваційних зрушень, що відповідають інноваційним процесам у зовнішньому середовищі,

- забезпечення перспективної ефективності, стійкої капіталізації та інноваційності.

Досліджуючи проблематику модернізації інфраструктурних підприємств у сучасних економічних умовах, сформулюємо основні закономірності їх розвитку, стають визначаючими факторами подальшого управління:

1. неузгодженість українського законодавства із законодавством західноєвропейських країн; відсутність єдиної державної транзитної політики;

2. недостатня якість перевезень через недосконалість транспортної інфраструктури;

3. відставання розвитку енергетичної системи через високий рівень монополізму і низькі темпи формування ринку енергетики;

4. недостатній розвиток інформаційно-логістичних систем;

5. удосконалення принципових положень інвестиційно-проєктних відносин між економічними суб'єктами господарювання з посиленням важелів активізації залучення іноземного та приватного капіталу на умовах збереження національних інтересів;

6. активізація інституційного стимулювання інвестування в розвиток загальнодержавних та регіональних інфраструктурних об'єктів;

\footnotetext{
${ }^{1}$ Петрович, Й. М., Савоніна, Н. С. (2018). Інноваційні засади модернізації організування виробничої діяльності промислових підприємств. Економіка: реалії часу, 2 (36), 5-16.

${ }^{2}$ Федулова, Л. І. (2008). Технологічна модернізаиія промисловості Украӥни. Київ: Четверта хвиля.

${ }^{3}$ Ареф'єва, О. В., Вовк, О. М. (2020). Адаптивне управління підприємствами в умовах неотехнологічного відтворення. Київ: ФОП Маслаков.

${ }^{4}$ Кучерук, Г. Ю., Тимощук, О. М., Вовк, О. М., Мельник, О. В. (2020). Якість логістизайї транспортних послуг: інвестииійний аспект. Київ: СІК ГРУП УКРАЇНА.

${ }^{5}$ Тульчинська, С. О., Шашина, М. В. (2019). Інтелектуально-інноваційна детермінанта процесів структурної модернізації економіки регіону. Причорноморські економічні студії, 37, 161-164.
} 
7. потреби міжнародного співробітництва та стандартизації провокують впровадження новітніх екологічних та енергоефективних технологій, що сприяють підвищенню рівня безпеки, якості та рентабельності підприємств інфраструктури;

8. дефіцит вузькопрофільних фахівців та робітничих працівників спровокували зростаючу потребу в нарощуванні професійних компетенцій та формуванні інтелектуального капіталу на підприємствах інфраструктурної сфери;

9. постійним є попит на інвестиційні ресурси та проєкти модернізації основних засобів і технологій;

10. соціально-освітні сфери стають майданчиком для надання нового виду послуг - приватної освіти, соціалізації, розвитку комунікацій, що стають дохідноутворюючими секторами економіки.

Отже, значну роль в рішенні задач модернізації підприємств інфраструктурної сфери починають відігравати напрями імплементації міжнародного права та інституційного стимулювання; мультимодальні транспортний-логістичні комплекси й системи управління транспортними об'єктами; поява послуг, які стають новими джерелами доходів й фінансування інноваційного розвитку.

Формування теоретико-метологічного базису управління модернізаційним процесом на підприємстві грунтується на сучасних теоріях і концепціях інноваційного розвитку економічних систем (рис.1.). Враховуючи тенденції та закономірності модернізації, сформульовано базове аксіологічне твердження щодо спрямованості реалізації модернізаційного процесу на підприємствах інфраструктурної сфери: «модернізація, грунтуючись на принципах інноваційної, стратегічності, інтелектуалізації, комерціалізації та ресурсоефективності, забезпечує інтелектуалізацію, цифровізацію та ефективність інноваційного розвитку підприємства».

Наукові припущення, гіпотези, дозволяють розкрити умови та перспективні напрями реалізації модернізаційних змін. Авторське бачення гіпотетичного базису формування організаційно-економічного механізму реалізації модернізаційного потенціалу підприємств інфраструктурної сфери наступне:

- модернізація спрямовується на технологічне оновлення, що забезпечує нарощування виробничого потенціалу та технологічну конкурентоспроможність;

- формує стійкість економічної системи та адаптивність до інноваційного розвитку,

- в процесі модернізації реалізується акумульований економічним потенціал та накопичені інвестиційні ресурси, що забезпечує ефективність їх застосування;

- під впливом модернізації формується новоутворений конкурентний потенціал за рахунок інноваційних технологій/продукції;

- управлінська модернізація спрямовується на внутрішню перебудову підприємства та формування нових інформаційних, трудових, фінансових потоків и;

- має спрямовуватись на стимулювання розвитку інноваційного потенціалу та інтелектуального капіталу.

Відповідно до формульованих наукових гіпотез основними практичними аспектами, які потрібно враховувати про формуванні механізму реалізації модернізаційного потенціалу, $\epsilon$ стратегічність та інноваційність управління, компетентнісний та знаннєвий характер змін, обгрунтованість методичного інструментарію.

Науковим підгрунтям формалізації організаційно-економічного механізму реалізації модернізаційного потенціалу підприємств інфраструктурної сфери є уже сформовані наукові підходи до побудови структури елементів та послідовності його впливів на забезпечення досягнення поставленої мети. Розкриваючи методологічні засади забезпечення ефективності реалізації модернізаційного потенціалу, зазначимо необхідність побудови структури організаційноекономічного механізму.

Поняття організаційно-економічного механізму в наукових дослідженнях часто використовується для формалізації інструментарію цілеспрямованого впливу суб'єктів управління на об'єкти, що забезпечує досягнення поставлених цілей. Механізм відображає послідовність, характер та об'єктність реалізації процесу управління підпорядкованими підсистемами підприємства. Важливим аспектом при побудові організаційно-економічного механізму $\epsilon$ конкретизація методологічного інструментарію та специфічних закономірностей внутрішнього і зовнішнього середовища підприємства. Так, до основних елементів механізму управління модернізаційними потенціалом віднесемо впливи зовнішнього та внутрішнього середовища, суб'єктів на об'єкти; цільову, управлінську, методичну та результуючу підсистеми. Окремо, розкриваючи управлінську підсистему, елементами механізму є цілі, закономірності, принципи, функції, методи й інструменти ї застосування, що формують подальшу спрямованість та парадигмальні приналежність управлінського інструментарію (рис.2). 


\section{ДЕТЕРМІНАНТА:}

запити на впровадження імперативів інноваційного розвитку( як чинник активізації інвестицій-інноваційного процесу, що провокує техніко-технологічне оновлення та формування нових компетенцій у персоналу для забезпечення стратегічних цілей ефективного функціонування).

ТЕОРЕТИЧНИЙ БАЗИС ПРОВЕДЕННЯ ДОСЛІДЖЕННЯ І ОБГРУНТОВАНОСТІ МОДЕРНІЗАЦІї:

- теорії: інноваційного розвитку, технологічних укладів, «нового індустріального суспільства».

- концепції: «креативної економіки», «інноваційного розвитку», «просторової дифузії інновацій», «поведінкової економіки», «адаптивної економіки», «цифрової економіки», «сталого розвитку», «довгих хвиль», «людиноцентричності», «корпоративної відповідальності» тощо.

\section{ПРАКТИЧНИЙ БАЗИС РЕАЛІЗАЦІЇ} МОДЕРНІЗАЦІЙНОГО ПОТЕНЦІАЛУ:

- формуються цілі, завдання і стратегії модернізації підприємства інфраструктурної сфери;

- окреслюються функції та форми модернізації;

- формується компетентнісний та знаннєвий базис для впровадження інновацій;

- обгрунтовується методичний інструментарій активізації інвестиційномодернізаційного процесу, оцінювання і контролю ефективності реалізації модернізаційних заходів,

- формуються етапи, інвестиційноінноваційні проєкти модернізації.
АКСІОМА МОДЕРНІЗАЦІЇ ПІДПРИЕМСТВА

ІНФРАСТРУКТРУНОЇ СФЕРИ:

Відповідно до інноваційної парадигми підприємства інфраструктурної сфери відбувається на принципах інноваційної, стратегічності, інтелектуалізації, комерціалізації

та ресурсоефективності. Модернізація забезпечує інтелектуалізацію, цифровізацію

та ефективність інноваційного розвитку підприємства.

\section{ГІПОТЕЗИ ДОСЛІДЖЕННЯ:}

- модернізація спрямовується на технологічне оновлення, що забезпечує нарощування виробничого потенціалу та технологічну конкурентоспроможність;

- формує стійкість економічної системи та адаптивність до інноваційного розвитку,

- в процесі модернізації реалізується акумульований економічним потенціал та накопичені інвестиційні ресурси, що забезпечує ефективність їх застосування;

- під впливом модернізації формується новоутворений конкурентний потенціал за рахунок інноваційних технологій/продукції;

- управлінська модернізація спрямовується на внутрішню перебудову підприємства та формування нових інформаційних, трудових, фінансових потоків и;

- має спрямовуватись на стимулювання розвитку інноваційного потенціалу та інтелектуального капіталу.

\section{Рис. 1. Методологічні засади формування економічного механізму} модернізації підприємства

Джерело: запропоновано автором. 
Зовнішнє середовище: сформований інноваційний, інформаційний та знаннєвий простір

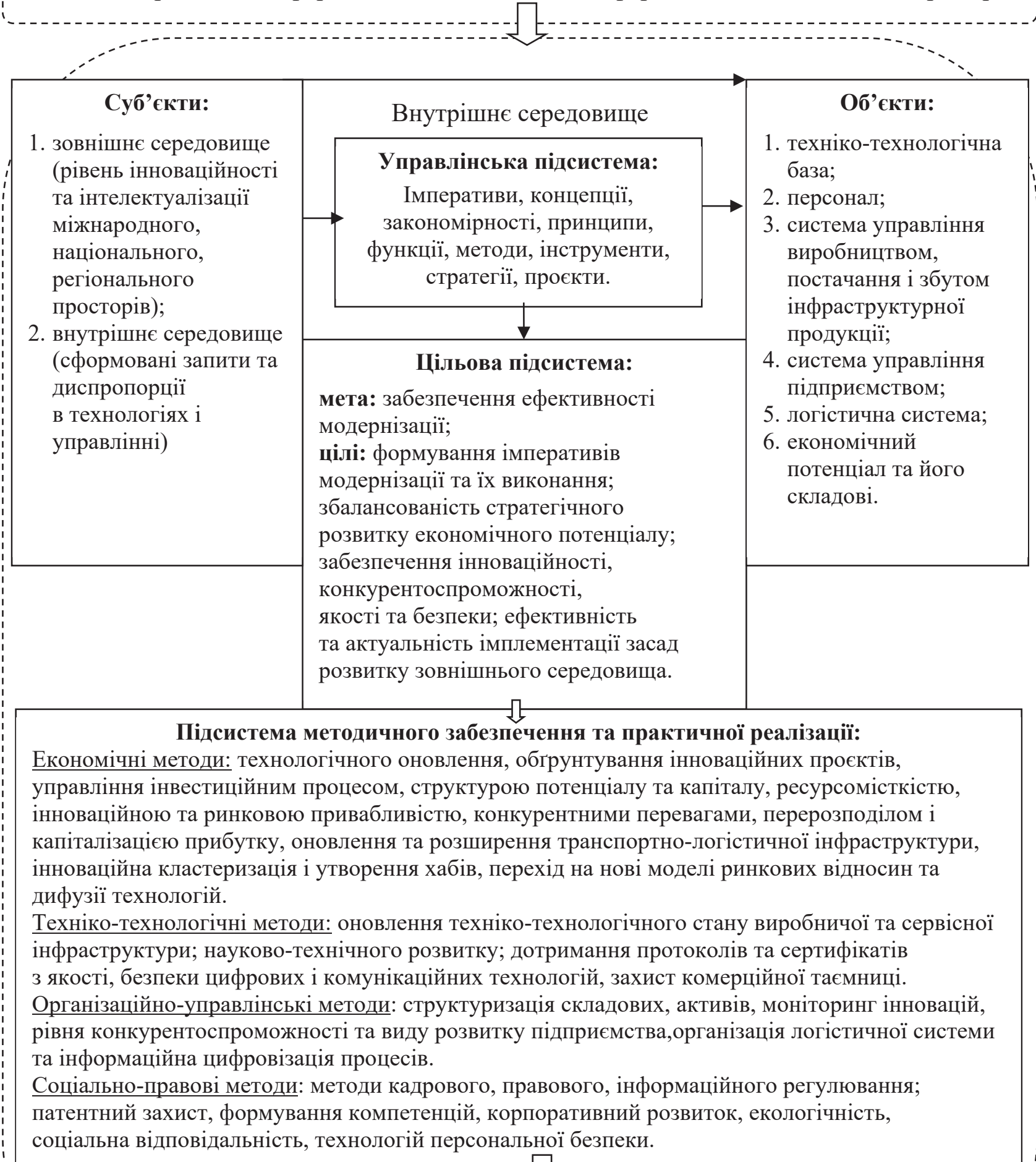
соціальна відповідальність, технологій персональної безпеки.

Підсистема результатів:

Нарощування модернізаційного потенціалу з подальшим забезпеченням ефективності реалізації інвестиційного, інноваційного, виробничого потенціалів та забезпечення стійкості й інноваційності підприємства інфраструктурної сфери

Рис. 2. Схема організаційно-економічного механізму модернізації підприємств інфраструктурної сфери 
Особливої уваги в процесах модернізації підприємств інфраструктурної сфери потребує обгрунтування методичного інструментарію. Підсистема методів управління, на нашу думку, має об'єднувати:

- економічні методи: технологічного оновлення, обгрунтування інноваційних проєктів, управління інвестиційним процесом, структурою потенціалу та капіталу, ресурсомісткістю, інноваційною та ринковою привабливістю, конкурентними перевагами, перерозподілом і капіталізацією прибутку, оновлення та розширення транспортно-логістичної інфраструктури, інноваційна кластеризація і утворення хабів, перехід на нові моделі ринкових відносин та дифузії технологій.

- техніко-технологічні методи: оновлення техніко-технологічного стану виробничої та сервісної інфраструктури; науково-технічного розвитку; дотримання протоколів та сертифікатів 3 якості, безпеки цифрових і комунікаційних технологій, захист комерційної таємниці.

- організаційно-управлінські методи: структуризація складових, активів, моніторинг інновацій, рівня конкурентоспроможності та виду розвитку підприємства,організація логістичної системи та інформаційна цифровізація процесів.

- соціально-правові методи: методи кадрового, правового, інформаційного регулювання; патентний захист, формування компетенцій, корпоративний розвиток, екологічність, соціальна відповідальність, технологій персональної безпеки.

Необхідно відмітити, що застосування тих чи інших методів реалізації модернізаційного потенціалу має відповідати парадигмі інноваційного розвитку та бути адаптованим до умов господарювання підприємства - об’єкта модернізаційних змін.

Висновки та перспективи подальших досліджень. Проведено дослідження дозволило на основі формалізації сучасних закономірностей описати методологічні засади модернізації підприємств інфраструктурної сфери. Так, потреби в імплементації досягнень науковоінтелектуального прогресу; активізації кластеризації інноваційних, логістичних, соціальноекономічних, знаннєвих просторів; формування ринків послуг, які стають новим и джерелами доходів й фінансування інноваційного розвитку провокують запити щодо прискорення модернізаційних процесів. Автором обгрунтовано теоретичні та практичні методологічні засади управління модернізаційним потенціалом підприємств інфраструктурної сфери. Розкрито поняття та структуру та послідовність реалізації організаційно-економічного механізму модернізації підприємств інфраструктурної сфери. Подальші дослідження необхідно спрямувати на обгрунтування інструментарію забезпечення ефективності, стійкості й інноваційності модернізації підприємства інфраструктурної сфери.

\section{References:}

1. Kasich, A. O. (2017). Modernizatsiini protsesy v Ukraini v konteksti svitovoho dosvidu [Modernization processes in Ukraine in the context of world experience]. Ekonomika Ukrainy. [Ukraine economy], 9 (670), 38-58. [in Ukrainian].

2. Baldzhy, M. D. (2015). Sutnist modernizatsii v konteksti suchasnoi ekonomichnoi katehorii. [The essence of modernization in the context of the modern economic category]. Naukovyi visnyk Khersonskoho derzhavnoho universytetu. [Scientific Bulletin of Kherson State University], 11, 64-67. [in Ukrainian].

3. Pepa, T., Cherniuk, L. (2017). Potentsial modernizatsii yak bazys efektyvnoho sotsialno-ekonomichnoho rozvytku krainy v konturi vidtvoriuvalnykh protsesiv [The potential of modernization as a basis for effective socioeconomic development of the country in the contour of reproduction processes]. Zbirnyk naukovykh prats ChDTU. [Collection of scientific works of ChSTU], 44, $42-49$ [in Ukrainian].

4. Petrovych, Y. M., Savonina, N. S. (2018). Innovatsiini zasady modernizatsii orhanizuvannia vyrobnychoi diialnosti promyslovykh pidpryiemstv [Innovative principles of modernization of the organization of production activity of industrial enterprises]. Ekonomika: realii chasu [Economy: the realities of time], 2(36), 5-16. [in Ukrainian].

5. Fedulova, L. I. (2008). Tekhnolohichna modernizatsiia promyslovosti Ukrainy [Technological modernization of Ukrainian industry]. Kyiv: Chetverta khvylia. [in Ukrainian].

6. Arefieva, O. V., Vovk, O. M. (2020). Adaptyvne upravlinnia pidpryiemstvamy v umovakh neotekhnolohichnoho vidtvorennia: monohrafiia [Adaptive management of enterprises in terms of neotechnological reproduction]. Kyiv: FOP Maslakov. [in Ukrainian].

7. Kucheruk, H. Yu., Tymoshchuk, O. M., Vovk, O. M., Melnyk, O. V. (2020). Yakist lohistyzatsii transportnykh posluh: investytsiinyi aspekt [Quality of logistics of transport services: investment aspect]. Kyiv: SIK HRUP UKRAINA. [in Ukrainian].

8. Tulchynska, S. O., Shashyna, M. V. (2019). Intelektualno-innovatsiina determinanta protsesiv strukturnoi modernizatsii ekonomiky rehionu [Intellectual and innovative determinant of the processes of structural modernization of the region's economy]. Prychornomorski ekonomichni studii [Black Sea Economic Studies], 37, 161-164. [in Ukrainian]. 